\title{
The Impact of Ownership Structure on Listed Firms' Performance in Vietnam
}

\author{
Dut Van VO', Truc Viet Thanh TRAN², Nga Thi Phuong DANG ${ }^{3}$
}

Received: August 01, 2020 Revised: September 20, 2020 Accepted: October 05, 2020

\begin{abstract}
The aim of this study is to estimate the impact of ownership structure on the performance of listed firms in transition economy. Buiding upon agency theory, hypotheses on such relationship are proposed. A detailed panel data of 502 non-financial companies listed on Ho Chi Minh Stock Exchange and Hanoi Stock Exchange over the period from 2013 to 2018, and the system generalized method of moment estimation are employed to test the proposed hypotheses. To ensure the reliability of data, this study excludes companies that violate information disclosure regulations or that are subject to special supervision by the State Securities Commission of Vietnam. Some firms with inadequate information, firms that lack the financial data required for creating variable or firms that have inconsistent construction are also re-screened. We only collect the data of enterprises that have ownership structure of two or more components. Estimation results reveal that state ownership has an U-shaped relationship with the performance of Vietnamese listed firms, while foreign ownership and the degree of ownership concentration have an inverted U-shaped relationship with listed firms' performance. The article provides governance implications that Vietnamese listed firms should decrease state ownership and foreign ownership to improve firm performance in order to boost investors' confidence.
\end{abstract}

Keywords: Firm Performance, Ownership Concentration Degree, State Ownership, Foreign Ownership

JEL Classification Code: G32, G34, N25

\section{Introduction}

In recent decades, corporate ownership structure has become a topic of broad public interest in Vietnamese firms. This issue is of greater concern when the privatization of State-owned enterprises (SOEs) in Vietnam began in 1992 and recently, when the restructuring plan of State-owned

${ }^{1}$ First Author and Corresponding Author. Associate Professor, Department of International Business, School of Economics, Can Tho University, Vietnam [Postal Address: School of Economics, Can Tho University, Campus II, 3/2 Street, Can Tho City, 900000, Vietnam] Email: vvdut@ctu.edu.vn

${ }^{2}$ Lecturer, Department of Finance and Banking, School of Economics, Can Tho University, Vietnam. Email: tvttruc@ctu.edu.vn

${ }^{3}$ Import-Export Staff, Cong Thai Hoc Loktek Co., Ltd. Vietnam [Postal Address: 56C - 57, Long Giang Industrial Zone, Tan Phuoc District, Tien Giang Province, Vietnam] Email: dangthiphuongnga193@gmail.com

(C) Copyright: The Author(s)

This is an Open Access article distributed under the terms of the Creative Commons Attribution Non-Commercial License (https://creativecommons.org/licenses/by-nc/4.0/) which permits unrestricted non-commercial use, distribution, and reproduction in any medium, provided the original work is properly cited. enterprises was approved in 2012 (Decision No. 929 / QD-TTg) involving changing the ownership structure of state-owned enterprises. One of the subjects that are being considered in the corporate restructuring process is the withdrawal of state capital or the participation of more shareholders, especially foreign shareholders. Different groups of shareholders will have different interests, benefits, relationships with governments, banks and strategic partners, so ownership structure has a great influence on corporate decisions and impact on firm performance.

In addition, the characteristics of the ownership model in Vietnam are that large proportion of shares are owned by the Board of Directors (BOD), making up a large proportion of internal shareholders, which lead to the possibility that information is not highly transparent. Therefore, agency problem has become a long-standing problem for Vietnamese businesses. Both academics and managers have raised the question how to solve the agency problem on the basis of ownership structure, especially when the degree of ownership concentration is concerned. Although numerous studies investigated the effect of 
ownership structure on firm performance in developed countries, the results of these studies have not reached a consensus. Therefore, it is necessary to carry on a more in-depth study of the relationship between ownership structure and corporate performance in a transition economy like Vietnam. We believe that the empirical evidence of this study is able to provide new insights about the typical characteristics of a transition economy with a highly uncertain institutional environment (Vo et al., 2018). Therefore, this study aims to investigate the effect of ownership structure on the performance of firms listed on the Vietnamese stock market to provide an empirical evidence to serve as a foundation for the interpretation of this relationship in the context of transition economy like Vietnam.

\section{Literature and Hypothesis Development}

To examine the effects of ownership structure and the performance of firms listed on the Vietnamese stock market, the article uses Agency theory (Jensen \& Meckling, 1976) as the foundation of developing arguments and theoretical model.

Agency theory assumes that ownership structures can affect firm performance due to the conflicts between the managers of a business and shareholders (Putterman, 1993). The agency problem arises, which in turn gives rise to agency costs. Given the nature of the agency relationship, business manager tends to seek his/her own personal interests rather than to act in the best interest of the firm and its shareholders.

Also related to the principal-agent problem in the business, Jensen and Meckling (1976) stated that the degree of managerial ownership in the enterprise contributes to the convergence of the interests of shareholders and manager and, thus, alleviating the agency problem. At the same time, this also encourages an increase in managerial ownership in order to maximize firm value. However, this approach causes two effects between ownership structure and the performance of joint stock company: the convergence effect and the entrenchment effect. The convergence effect suggests that there is a positive correlation between firm capitalization and managerial ownership. Meanwhile, the entrenchment effect supposes that the correlation is negative because a large percentage of shares held by manager prevents the market from controlling the firm. Therefore, this exacerbates the agency problem in the business.

With the characteristics of state ownership in countries with major government intervention in economic activities, state ownership has a negative influence on the firm performance when the state owners hold large proportion of shares, but not other shareholders. State shareholders who are individual representatives incur agency theory and agency costs. Representative shareholders may not operate for the sake of efficiency and not act in the best interest of the firm, which leads to the consequence that a high degree of state ownership has a negative impact on the company's performance. In contrast, foreign ownership is seen as the ownership of foreign private investors. When foreign investors are allowed to own equity capital of domestic companies, the company's performance will be enhanced as foreign investors participate in and are responsible for the firm operations. In turn, improving firm performance also benefits foreign shareholders who join capital in the company.

Adopting the standpoints of the agency theory, so far, several studies have investigated ownership structure and firm performance. Vo (2014) points out that the higher the ownership of the company, the higher the firm performance and firm value. Another study conducted by Nguyen and Nguyen (2017) shows that foreign ownership negatively affects pharmaceutical firm performance in terms of Tobin's Q, but when foreign ownership reaches above 24.4 percent, the correlation becomes positive. Institutional and individual foreign ownership also have an U-shaped relationship with the listed firm performance. Additionally, Nguyen and Ngo (2017) claim that foreign ownership is negatively correlated with firm's performance (as measured by Tobin's Q). Apart from that, factors such as financial leverage, liquidity and the number of employees also influence the value of listed firms. These authors suggest that, in order to improve management efficiency and to increase enterprise value, firm should increase the degree of foreign ownership by expanding. At the same time, Greenaway et al. (2009) stated that when foreign ownership increases from 47 percent to 61 percent, firm performance increases. But when foreign ownership continues to increase, firm performance will decline. The authors also indicate that foreign owners from Hong Kong, Macao and Taiwan influence the firm performance in China most. Foreign owners have more opportunities to approach superior technology, talented managers, and financial resources. Besides that, foreign owners supervise managers and, thus, reduce agency costs. Managers in firms with large proportion of shares held by foreign investors can fully perform controlling function because they focus more on long-term value. Moreover, when foreign ownership is concentrated, foreign ownership can improve the firm performance because foreign investors can transfer financial and technological resources to the business. Gurbuz and Aybars (2010) found that foreign ownership significantly improves the financial performance of firms in Turkey to a certain extent. However, it does not mean that the greater the 
Dut Van VO, Truc Viet Thanh TRAN, Nga Thi Phuong DANG /

percentage of shares held by foreign investors, the higher the profit for the business. Meanwhile, Gedajlovic et al. (2005) stressed that foreign ownership corresponding to the percentage of outstanding shares held by foreign investors was positively and significantly correlated with the dividend pay-out ratio.

Through the comprehensive review of prior studies related to the research topic, it is important to address that the significant difference in this study compared to prior studies is the combined use of the market indicator, which is Tobin's Q, and the accounting indicator, which is $\mathrm{ROA}$, to reflect profitability so as to investigate the effect of ownership structure on the firm performance. At the same time, this study also uses the industry-adjusted ROA in model test extensions to fine-tune performance among different businesses in different industries. Then, the estimation of the firm performance will be more accurate. It can also help minimize economic problems and external impacts. The prior studies only used simple quantitative methods and panel data over a short time period. However, the listed companies over a short period of time are not the same. Therefore, this study employs unbalanced panel data analysis over a period of five years or more to overcome shortcomings in data collection and processing. This gives more convincing results.

\section{The degree of ownership concentration}

The impact of ownership structure on corporate performance stems from a conflict of interest among shareholders. When the interests of the shareholders do not align, the concentration of ownership focuses on the group of block holders. Cuervo (2002) argued that, when the block holders own a large proportion of shares, these shareholders could impose their interests over corporate interests and take advantage of the small shareholders. On the other hand, the degree of ownership concentration can improve firm performance due to strictly monitoring managers. Consequently, the concentration of ownership may have a non-linear relationship with firm performance. This shows that the degree of ownership concentration has a positive effect at first and will have a negative effect when shareholders gain too much power. These results support the following hypothesis:

H1: Concentration of ownership has an inverted $U$-shaped nonlinear relationship with the performance of Vietnamese listed firms.

\section{State ownership}

Wei et al. (2005) provided important evidence that state ownership has an U-shaped nonlinear relationship with firm performance. When state ownership reaches a critical point, which is the most optimal or the lowest point for ownership structure, firm performance decreases as the number of shares held by the state owners increases. This is because the state shareholders care about political rather than economic benefits. But when state ownership passes the limit, firm performance increases. The reason is that state ownership is ineffective in maximizing profits and managing the business. When the state shareholder becomes the dominant shareholder, the political relationships and the power of the state shareholder can help enhance the firm performance by sending a positive signal to the market, effectively participating in supervising management and providing support to struggling SOEs as state ownership has many advantages to access to resources. From the above arguments, this study proposes the second hypothesis as follows:

H2: State ownership has an U-shaped nonlinear relationship with the performance of Vietnamese listed firms.

\section{Foreign ownership}

Most studies suggest that foreign ownership has a positive effect on firm performance because foreign shareholders can play a supervisory role in internal corporate governance mechanism. Kim (2011) argues that foreign ownership helps alleviate agency problems and cut internal costs because foreign shareholders focus on long-term rather than short-term benefits. However, foreign investors do this only when they are able to take control of firm, in other words, when they become block holders. Additionally, foreign shareholders contribute to the improvement of corporate governance due to the dynamism gained from investment operations and the application of more progressive corporate governance standards in the business. Foreign ownership also enhances market efficiency by increasing financial capacity and distributing more dividends. Therefore, it can be argued that foreign ownership in the role of a supervisor can boost firm performance. However, this positive effect may disappear when foreign ownership accounts for a large proportion of the ownership structure. Hence, the third hypothesis is proposed as follows:

H3: Foreign ownership has an inverted U-shaped nonlinear relationship with the performance of Vietnamese listed firms.

From the above arguments and based on the results of prior studies, the research model is generalized through Figure 1. 


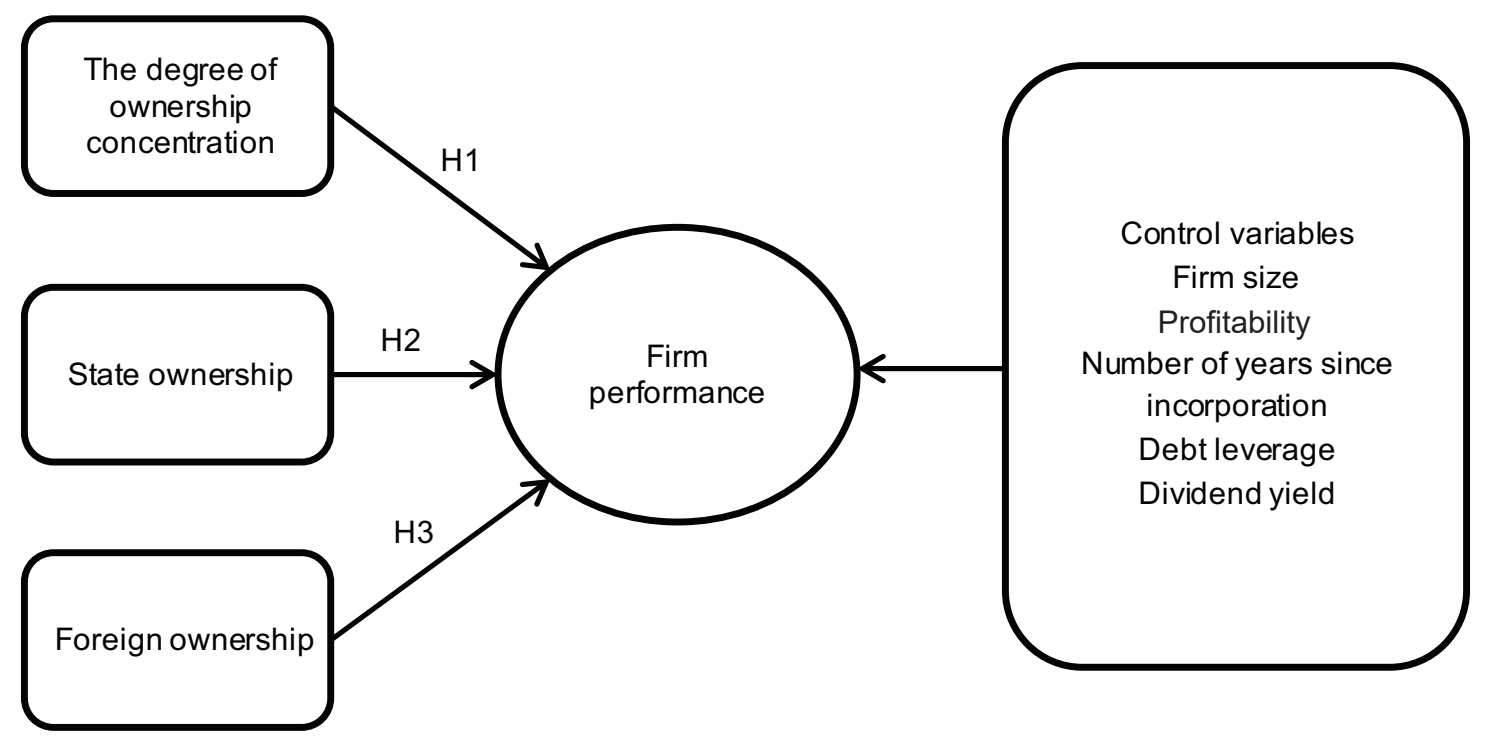

Figure 1: Theoretical Model

\section{Research Methodology}

\subsection{Sample Selection}

To test the proposed hypotheses, the article uses unbalanced panel data including 502 non-financial companies listed on the HOSE and HNX. Data are collected during the period from 2013 to 2018. Therefore, the number of observations in this study is 3,012. To ensure the reliability of data, this study excludes companies that violate information disclosure regulations or that are subject to special supervision by the State Securities Commission of Vietnam. Some firms with inadequate information, firms that lack the financial data required for creating variable or firms that have inconsistent construction are also re-screened to increase the reliability of the data sample. Furthermore, this study also excludes the enterprises with 100 percent ownership structure belonging to one component from the sample, and only collects the data of enterprises that have ownership structure of two or more components. The data used in this empirical analysis are collected and calculated from secondary data through such listed firms' audited annual consolidated financial statements, including balance sheets, income statements, cash flow statements, financial statements notes, and prospectus.

\subsection{Definition and Measurement of Variables}

Dependent variable (Y): the performance of listed companies is measured by Tobin's Q ratio (Nguyen et al., 2019). Specifically, it is calculated by the following formula:
Tobin's $Q=\frac{\text { Market capitalization }+ \text { Book value of Liabilities }}{\text { Total assets }}$

Additionally, Kato and Long (2006) suggested applying industry adjustment for the ROA ratio. This is adopted by several previous studies (Nguyen et al., 2019; Nguyen \& Nguyen, 2020). Therefore, this study uses the adjusted values calculated as follows:

$$
R O A=\frac{\text { Net profit }}{\text { Average total assets }}
$$

$$
A D J R O A=\operatorname{sign}(R O A-I D M r) * \sqrt{\left(R O A-I D M_{r}\right)}
$$

Independent variable $\left(X_{1}\right)$ : Ownership structure

Independent variables in this study include state ownership, foreign ownership, and the degree of ownership concentration.

Following previous studies (Gurunlu \& Gursoy, 2010; Nguyen et al., 2019; Vu et al., 2020), state ownership variable and foreign ownership variable based on the study of, as follows:

$$
\begin{gathered}
\text { State ownership }=\frac{\begin{array}{c}
\text { Thenumber of shares held by } \\
\text { the state owners }
\end{array}}{\begin{array}{c}
\text { The total number of shares } \\
\text { The number of shares held by }
\end{array}} \\
\text { Foreign ownership }=\frac{\text { foreign investors }}{\text { The total number of shares }}
\end{gathered}
$$


The last independent variable in this study is the degree of ownership concentration, which is generalized through the following formula:

$$
H H I=\sum_{i=1}^{n} S_{i}^{2}
$$

Where $\mathrm{S}_{i}$ is the percentage of shares owned by block holders and $\mathrm{n}$ is 5 shareholders owning more than 5 percent of shares. This index has a value ranging from 0 to 10,000 and higher value of the HHI index indicates a higher level of ownership concentration.

\section{Control variables}

Firm size represents the financial resources of the business and the competitive position of a business in the same industry. Therefore, firm size has a positive correlation with firm performance. In this study, firm size is measured by the logarithm of total assets (Doğan, 2013).

Profitability, which is measured by the ratio of operating income (earnings before interest and taxes) to revenue (Chen \& Ho, 2000), shows a business's ability to generate profits. Highly profitable firms have high firm performance. Prior studies also found a positive relationship between firm profitability and firm performance (Gurbuz \& Aybars, 2010; Nguyen \& Nguyen, 2020).

Number of years since incorporation is defined as the number of years from when the firm was registered its business (Shumway, 2001). Old-established firms gain a lot of experience, which can help enhance firm performance
(Gurbuz \& Aybars, 2010). In this study, the number of years since incorporation is measured by the number of years since the firm has been operated in the market (Choi et al., 2012).

Total debt leverage measures the extent to which nonequity capital is used to finance a business's operations. Previous studies have suggested that the use of corporate debt leverage has a negative impact on firm's performance (Gurbuz \& Aybars, 2010). In this study, total debt leverage is measured by total debt divided by the stock's market value (Pedersen \& Thomsen, 1999).

Dividend yield is the firm's dividend payout ratio. High dividend payment means that the business retains less profit for reinvestment and vice versa. At the same time, it also implies high return expectations in the future. Numerous empirical evidences suggest that there is a positive correlation between dividend payout and firm performance. This study uses dividend per share and earnings per share to measure dividend yield (Gurbuz \& Aybars, 2010).

\subsection{Estimation Method}

With the measurement method of dependent variable and the use of panel data, this paper employs the system GMM estimation to investigate the relationship between ownership structure and firm performance. The estimation equation is shown as follows:

$$
F P_{i t}=\alpha+\gamma F P_{i, t-1}+\beta_{1} O W N_{i t}+\beta_{2} O W N_{i t}^{2}+\beta_{3} X_{i t}+\varepsilon_{i t}
$$

\begin{tabular}{|c|c|c|}
\hline Variables & Measurement Method & $\begin{array}{l}\text { Expected } \\
\text { Signs }\end{array}$ \\
\hline \multirow{2}{*}{ Firm performance (FP) } & Tobin's $Q=\frac{\text { Market capitalization }+ \text { Book value of Liabilities }}{\text { Total assets }}$ & \\
\hline & $\begin{array}{l}\text { Industry-adjusted return on assets ADJROA } \\
=\operatorname{sign}\left(\mathrm{ROA}-\mathrm{IDM}_{\mathrm{r}}\right) * \sqrt{\left(\mathrm{ROA}-\mathrm{IDM}_{\mathrm{r}}\right)}\end{array}$ & \\
\hline \multirow{3}{*}{$\begin{array}{l}\text { Ownership structure } \\
\text { (OWN) }\end{array}$} & State ownership $(\mathrm{SO})=\frac{\text { The number of shares held by the state owners }}{\text { The total number of shares }}$ & U-shaped \\
\hline & Foreign ownership $(\mathrm{FO})=\frac{\text { The number of shares held by foreign investors }}{\text { The total number of shares }}$ & $\begin{array}{l}\text { Inverted } \\
\text { U-shaped }\end{array}$ \\
\hline & The degree of ownership concentration (CONC) is measured by $\mathrm{HHI}=\sum_{i=1}^{n} \mathrm{~S}_{\mathrm{i}}^{2}$ & $\begin{array}{l}\text { Inverted } \\
\text { U-shaped }\end{array}$ \\
\hline Firm size (SIZE) & The logarithm of total assets & $(+)$ \\
\hline Profitability (PROFIT) & Operating income/Revenue & $(+)$ \\
\hline $\begin{array}{l}\text { Number of years since } \\
\text { incorporation (AGE) }\end{array}$ & The logarithm of the total number of years since the firm was listed & $(+)$ \\
\hline Total debt leverage (LEV) & Total liabilities/Total assets & $(-)$ \\
\hline Dividend yield (DY) & Dividend per share/Earnings per share & $(+)$ \\
\hline
\end{tabular}

Table 1: Summary of Ownership Structure and Control Factors Affecting Firm Performance 
Where $\mathrm{FP}_{\mathrm{it}}$ is the performance of firm $\mathrm{i}$ at time $\mathrm{t}, \mathrm{FP}_{\mathrm{i}, t-1}$ is the performance of firm $\mathrm{i}$ at time $\mathrm{t}-1, \mathrm{OWN}_{\mathrm{it}}$ is the ownership structure of firm i at time $t, \mathrm{OWN}_{\mathrm{it}}{ }^{2}$ is the square of the ownership structure of firm $i$ at time $t, X_{i t}$ are the control variables of firm $i$ at time $t, \varepsilon_{i t}$ is error term. Table 1 summarizes the characteristics of the variables in the research model and the expected signs about the impact of the independent and control variables on the dependent variable.

\section{Results and Discussion}

\subsection{Empirical Results}

Table 2 illustrates mean, standard deviation, minimum and maximum value, and variance inflation factor (VIF). The VIF values for all independent variables noted in the model are below 2.0 (see Table 2). Thereby, it can be concluded that multicollinearity is no issue in our current models when these variables are included in our research models.

Based on the results of the correlation matrix in Table 3.a and 3.b, it can be seen that all the pairs of correlation coefficients among the variables in the model are less than 0.8 ; the maximum value of the correlation coefficients is 0.475 - the correlation between the degree of ownership concentration and state ownership. These results imply that the estimated results are statistically unbiased (see Table 3.a and 3.b).

Table 4 presents the estimation results by using system GMM method. The estimation of the system GMM is disclosed in two models: Model 1 with Tobin's Q as the dependent variable and Model 2 with IDMr as the dependent variable.

Table 2: Descriptive Statistics and Multicollinearity Test among the Variables in the Model $(\mathrm{N}=3,012)$

\begin{tabular}{|l|c|c|c|c|c|}
\hline Variables & Mean & Standard Deviation & Minimum & Maximum & VIF \\
\hline Tobin's Q & 0.99 & 0.59 & 0.08 & 15.88 & \\
\hline IDMr & 0.63 & 2.22 & -9.15 & 8.13 & \\
\hline SO & 0.24 & 0.17 & 0 & 0.69 & 1.38 \\
\hline FO & 0.13 & 0.12 & 0 & 0.54 & 1.24 \\
\hline CONC & 0.19 & 0.14 & 0 & 0.98 & 1.34 \\
\hline AGE & 1.09 & 0.30 & 0 & 1.77 & 1.14 \\
\hline SIZE & 5.71 & 0.62 & 4.11 & 8.16 & 1.40 \\
\hline LEV & 0.51 & 0.22 & 0 & 1.03 & 1.23 \\
\hline PROFIT & 1.87 & 23.55 & 0 & 1226.61 & 1.01 \\
\hline DY & 7.01 & 10.86 & 0 & 166.67 & 1.03 \\
\hline
\end{tabular}

Table 3.a: Correlation Matrix among the Variables in the Model $(N=3,012)$

\begin{tabular}{|c|c|c|c|c|c|c|c|c|c|}
\hline Variable & 1 & 2 & 3 & 4 & 5 & 6 & 7 & 8 & 9 \\
\hline Tobin's Q & 1.000 & & & & & & & & \\
\hline So & 0.030 & 1.000 & & & & & & & \\
\hline FO & $0.143^{\text {t** }}$ & $-0.212^{* * *}$ & 1.000 & & & & & & \\
\hline CONC & $0.110^{* * *}$ & $0.475^{* * *}$ & $-0.031^{*}$ & 1.000 & & & & & \\
\hline SIZE & $0.097^{* \star *}$ & $-0.037^{* *}$ & $0.274^{* \star *}$ & $0.138^{* * * *}$ & 1.000 & & & & \\
\hline LEV & $-0.055^{* * *}$ & $0.035^{*}$ & $-0.143^{*+* x}$ & $0.100^{*+*}$ & $0.343^{*+* *}$ & 1.000 & & & \\
\hline PROFIT & -0.018 & $-0.046^{* *}$ & 0.016 & $-0.031^{*}$ & -0.028 & $-0.031^{*}$ & 1.000 & & \\
\hline AGE & $-0.066^{* * * *}$ & $-0.094^{*+*}$ & $0.232^{* * *}$ & 0.005 & $0.282^{4+*+1}$ & -0.028 & -0.025 & 1.000 & \\
\hline DY & $0.058^{*+*+*}$ & $0.105^{* * *}$ & $-0.111^{* * * t}$ & $0.031^{*}$ & -0.029 & $-0.055^{*}$ & -0.030 & $-0.117^{+*+*}$ & 1.000 \\
\hline
\end{tabular}

Note: ${ }^{*},{ }^{* *}$ and ${ }^{* * *}$ indicate statistical significance at the $10 \%, 5 \%$, and $1 \%$ level, respectively. 
Dut Van VO, Truc Viet Thanh TRAN, Nga Thi Phuong DANG /

Table 3.b: Correlation Matrix among the Variables in the Model $(N=3,012)$

\begin{tabular}{|c|c|c|c|c|c|c|c|c|c|}
\hline Variables & 1 & 2 & 3 & 4 & 5 & 6 & 7 & 8 & 9 \\
\hline IDMr & 1.000 & & & & & & & & \\
\hline so & $0.116^{* t+*}$ & 1,000 & & & & & & & \\
\hline FO & $0.105^{* t *}$ & $-0,212^{*+*}$ & 1,000 & & & & & & \\
\hline CONC & 0.027 & $0,475^{* * *}$ & $-0,031^{*}$ & 1,000 & & & & & \\
\hline SIZE & $-0.112^{* * *}$ & $-0,037^{* *}$ & $0,274^{* * *}$ & $0,138^{* * *}$ & 1,000 & & & & \\
\hline LEV & $-0.407^{4+2+x}$ & $0,035^{*}$ & $-0,143^{* * * *}$ & $0,100^{* * * *}$ & $0,343^{\text {tw*t }}$ & 1,000 & & & \\
\hline PROFIT & -0.019 & $-0,046^{* *}$ & $-0,016$ & $-0,031^{*}$ & 0,028 & $0,031^{*}$ & 1,000 & & \\
\hline AGE & -0.010 & $-0.094^{4 * * *}$ & $0,232^{* * *}$ & 0,010 & $0,282^{* * *+}$ & $-0,028$ & $-0,025$ & 1,000 & \\
\hline DY & $0.208^{* *+*}$ & $0,105^{* * *}$ & $-0,111^{* * *}$ & $0,031^{*}$ & $-0,029$ & $-0,055^{* * *}$ & $-0,030$ & $-0.117^{4 * t+}$ & 1,000 \\
\hline
\end{tabular}

Note: *, ${ }^{* *}$ and ${ }^{* * *}$ indicate statistical significance at the $10 \%, 5 \%$, and $1 \%$ level, respectively.

Table 4: Estimated Results of the Models Using GMM Estimation

\begin{tabular}{|l|c|c|}
\hline & Model 1 (Tobin's Q) & Model 2 (IDMr) \\
\hline L. Tobin's Q & $0.757^{* * *}(0.128)$ & $0.489^{* * *}(0.072)$ \\
\hline L. IDMr & - & $-4.770^{* *}(2.242)$ \\
\hline SO & $-2.807^{* * *}(0.952)$ & $8.260^{* *}(3.517)$ \\
\hline SOsq & $1.797^{*}(1.014)$ & $6.239^{* *}(2.512)$ \\
\hline FO & $2.096^{* * *}(0.662)$ & $-10.770^{* *}(5.298)$ \\
\hline FOsq & $-4.305^{* * *}(1.534)$ & $5.838^{* *}(2.593)$ \\
\hline CONC & $12.740^{* * *}(3.174)$ & $-8.562^{* *}(3.913)$ \\
\hline CONCsq & $-18.530^{* * *}(4.754)$ & $-0.152^{* *}(0.060)$ \\
\hline SIZE & $-0.083^{* * *}(0.032)$ & $-2.237^{* * *}(0.293)$ \\
\hline LEV & $-0.145^{* *}(0.070)$ & $0.003^{* *}(0.001)$ \\
\hline PROFIT & $0.018^{* *}(0.008)$ & $0.240^{* *}(0.114)$ \\
\hline AGE & $0.148^{* * *}(0.050)$ & $0.039^{* * *}(0.005)$ \\
\hline DY & $-0.001(0.002)$ & $0.618^{*}(0.376)$ \\
\hline Cons & $-0.467^{* * *}(0.175)$ & 3.012 \\
\hline N & 3.012 & 0.000 \\
\hline AR1 & 0.000 & 0.640 \\
\hline AR2 & 0.812 & 0.367 \\
\hline Sargan test & 0.128 & \\
\hline
\end{tabular}

Note: The values in parentheses () are adjusted standard errors, * ${ }^{* *}$ and ${ }^{* * *}$ indicate statistical significance at the $10 \%, 5 \%$, and $1 \%$ level, respectively.

\subsection{Discussion}

Ownership structure: The results of both models in Table 4 show that state ownership has an U-shaped nonlinear relationship with the performance of firms listed on the Vietnamese stock exchange. This finding is consistent with the second hypothesis. When state ownership reaches a limit, the firm performance decreases as the state owner pays more attention to political interests rather than economic benefits. However, as state ownership exceeds the limit, firm performance increases because when the state shareholder becomes the dominant shareholder, the political relationships and the power of the state shareholder can help increase firm performance. This result implies that the second hypothesis is accepted. 
In contrast, the results of the two models in Table 4 also present that foreign ownership has an inverted U-shaped nonlinear relationship with the performance of firms listed on the Vietnamese stock exchange. As foreign ownership becomes centralized, foreign shareholders will act to reduce agency problems by strengthening their supervisory role in the business and thus contribute to firm performance. However, when foreign investors become block holders, they possibly impair the managers' initiative in decisionmaking, invalidate the supervisory role of managers and may not align their interests with other shareholders, which leads to conflicts with minority shareholders. Therefore, a concentrated foreign ownership can reduce firm performance. This means that the third hypothesis cannot be rejected.

Similarly, the estimated results in Table 4 indicate that ownership concentration also has an inverted U-shaped nonlinear relationship with firm performance. This finding confirms that the first hypothesis cannot be rejected. When the degree of ownership concentration reaches a certain level, it will positively impact the firm performance. But when the concentration of ownership increases beyond a certain level, the correlation becomes negative. This indicates that the degree of ownership concentration has a positive effect at the beginning and will have a negative effect when shareholders gain too much power.

Firm size: Firm size has a negative impact on firm performance in both models. This can be seen from the results in Table 4, firm size has a negative correlation at the significance level of 1 percent $\left(\beta_{7}=-0.083 ; p<0.01\right)$ in Model 1 and at the significance level of 5 percent $\left(\beta_{7}=-0.152 ; p<0.05\right)$ in Model 2. This result is contrary to the original assumptions and previous studies (Doğan, 2013) as this study finds an inverse relationship between the market scale and firm performance. In fact, when the scale increases, the difficulty in operating and managing also increases. Moreover, businesses may have high production costs and fail to properly use capital, which will adversely affect the firm performance.

Total debt leverage: The negative relationship between total debt leverage and firm performance exists in both models because when firms use their total leverage improperly, they will face financial risks. The greater the total leverage, the higher the level of debt, which may lead to a decrease in firm performance. This is clearly shown through the research results in Table 4 that in Model 2, the estimated coefficient is negative $\left(\beta_{8}=-0,145 ; \mathrm{p}<0.05\right)$ at the significance level of 5 percent and in Model 1, the coefficient is also estimated to be negative $\left(\beta_{8}=-2,237 ; p<0.01\right)$ at the significance level of 1 percent. This result is completely consistent with the study of Gurbuz and Aybars (2010).

The impact of profitability on firm performance: The research results in both models provide support for the proposed hypothesis. This is shown through the profitability variable, which has a positive influence on the firm performance. In Model 1 with Tobin's Q as the dependent variable, profit has a positive estimated coefficient $\left(\beta_{9}=0.018 ; \mathrm{p}<0.05\right)$ at the significance level of $5 \%$. In Model 2, the estimated coefficient is also positive $\left(\beta_{9}=0.003 ; p<0.05\right)$ at the significance level of 5 percent. The reason for this positive relationship is that highly profitable firm generates more income and, thus, improves firm performance. The higher the gross profit, the higher the net profit, which indicates the better the effectiveness of management in the company. Thus, it will attract investors who can help raise the company's stock price. The results of the study are consistent with Gurbuz and Aybars (2010), where profitability is the relationship between sales and costs created by using both company's current and fixed assets in a business operation. The improvement of the business's profitability will help increase the expected return for investors in the future, making the firm perform better.

Number of years since incorporation: The estimated results from Model 1 with Tobin's Q as the dependent variable presented in Table 4 show that the number of years since incorporation has a positive relationship with the firm performance with the positive estimated coefficient $\left(\beta_{10}=0.148 ; \mathrm{p}<0.01\right)$ at the significance level of $1 \%$. This finding is consistent with prior studies such as Vo (2014). Similarly, the analysis results from Model 2 with IDMr as the dependent variable indicate that the number of years since incorporation positively affects firm performance with an estimated coefficient $\left(\beta_{10}=0.240 ; \mathrm{p}<0.05\right)$ at the significance level of $5 \%$. In fact, accumulated retained earnings will increase over time corresponding to the number of years since incorporation and this is a necessary source for the stable development of the business. Additionally, oldestablished enterprises have more competitive advantages in the market, reputation and managerial experience than those that are established later, and it also contributes to the increase in firm value.

Dividend yield on firm performance: From the estimated results in Table 4, it can be seen that dividend yield has a positive correlation with firm performance in Model 2 with the positively estimated coefficient $\left(\beta_{11}=0.039\right.$; $\mathrm{p}<0.01$ ) at the significance level of 1 percent. This finding is completely consistent with the study of Gurbuz and Aybars (2010). Dividend yield is the best and most reliable signal of a business's prospects. Paying high dividends shows that firm performance has improved and managers are committed to maximizing value for shareholders. Dividend yield is also one of the ways to help solve the agency problem and information asymmetry between managers and shareholders. 
Dut Van VO, Truc Viet Thanh TRAN, Nga Thi Phuong DANG /

\section{Conclusion, Implications and Research Limitations}

By adopting agency theory and previous empirical evidences, the study developed the theoretical arguments on the effect of ownership structure on listed firms' performance, and conducts tests to examine the effect of ownership structure on firm performance, as proxied by the Tobin's Q and IDMr, across a sample of 3,012 observations of 502 companies listed on the Vietnamese stock market from 2013 to 2018. The research results show that the relationship between ownership structure and firm performance is quite clear. Specifically, state ownership has an U-shaped nonlinear relationship, while foreign ownership has an inverted U-shaped nonlinear relationship with firm performance.

The empirical findings of the study imply that privatization enables to help to mitigate the severity of agency problem, which allows other investors and market to effectively monitor and control. Besides that, privatization can help reinvest and distribute company resources in a more efficient way. Hence, privatization is an effective way to improve the performance of SOEs.

Our findings also imply that policymakers in emerging markets like Vietnam with weak corporate governance mechanism may consider limiting foreign ownership. Policymakers should increase the foreign ownership limit or should loosen the "room" for foreign investors. Moreover, it is necessary to continue to maintain and accelerate the completion of legal frameworks for increasing foreign ownership.

Although the study has provided empirical evidence of the relationship between ownership structure and firm performance, it still has some limitations that may provide further development opportunities for more in-depth researches in Vietnam. Specifically, although meeting spatial and temporal data conditions for econometrics analysis, the length of time and the coverage of the research space are still limited. Therefore, studies with larger sample sizes are needed. In addition, this study focuses only on state ownership and foreign ownership. However, family ownership is common in the emerging market so research on family ownership in the context of Vietnam should be conducted in the future. Last, but not least, this study has not mentioned the difference between individual foreign investors and institutional foreign investors, which is a new development direction for the next studies.

\section{References}

Chen, S., \& Ho, K.W. (2000). Corporate diversification, ownership structure, and firm value-The Singapore evidence. International
Review of Financial Analysis, 9(3), 315-326. https://doi. org/10.1016/S1057-5219(00)00032-6.

Choi, H. M., Sul, W., \& Min, S. K. (2012). Foreign board membership and firm value in Korea. Management Decision, 50(2), 207-233. https://doi.org/10.1108/00251741211203533.

Cuervo, A. (2002). Corporate governance mechanisms: A plea for less code of good governance and more market control. Corporate Governance: An International Review, 10(2), 84-93. https://doi.org/10.1111/1467-8683.00272.

Doğan, M. (2013). Does firm size affect the firm profitability? Evidence from Turkey. Research Journal of Finance and Accounting, 4(4), 53-59.

Gedajlovic, E., Yoshikawa, T., \& Hashimoto, M. (2005). Ownership structure, investment behaviour and firm performance in Japanese manufacturing industries. Organization Studies, 26(1), 7-35. https://doi.org/10.1177/0170840605046346.

Gurbuz, A. O., \& Aybars, A. (2010). The impact of foreign ownership on firm performance, evidence from an emerging market: Turkey. American Journal of Economics and Business Administration, 2(4), 350-359. https://doi.org/10.3844/ajebasp. 2010.350.359.

Gurunlu, M., \& Gursoy, G. (2010). The Influence of foreign ownership on capital structure of non-financial firms: Evidence from Istanbul stock exchange. The IUP Journal of Corporate Governance, 9(4), 21-29.

Greenaway, D., Guariglia, A., \& Yu, Z. (2009). The more the better? Foreign ownership and corporate performance in China. The European Journal of Finance, 20(7-9), 681-702. https://doi. org/10.2139/ssrn.1448509.

Jensen, M., \& Meckling W. (1976). Theory of the firm: managerial behavior, agency costs, and ownership structure. Journal of Financial Economics, 3(4), 305-60. https://doi. org/10.1016/0304-405X(76)90026-X.

Kato, T., \& Long, C. (2006). CEO turnover, firm performance, and enterprise reform in China: Evidence from micro data. Journal of Comparative Economics, 34(4), 796-817. https://doi. org/10.1016/j.jce.2006.08.002.

Kim, B. (2011). Do foreign investors encourage value-enhancing corporate risk taking?. Emerging Markets Finance and Trade, 47(3), 88-110. https://doi.org/10.2753/REE1540496X470305.

Nguyen, A. P., \& Ngo, P. T. (2017). The impact of foreign ownership and size on firm performance. Hue University Journal of Science: Economics \& Development, 126(5C), 75-85. https:// doi.org/10.26459/hueuni-jed.v126i5D.4489.

Nguyen, A. P., Nguyen, H. A., Ngo, T. P., \& Nguyen, V. P. (2019). The Relationship between Productivity and Firm's Performance: Evidence from Listed Firms in Vietnam Stock Exchange. Journal of Asian Finance, Economics and Business, 6(3), 131-140. https://doi.org/10.13106/jafeb.2019.vol6.no3.131.

Nguyen, T. H. H., \& Nguyen, T. L. (2017). Evaluation of the relationship between foreign ownership and the performance of 
listed firms in Vietnam. Journal of Vietnam's Socio-Economic Development, 90(2), 53-67.

Nguyen, T. N. L., \& Nguyen, V.C. (2020). The determinants of profitability in listed enterprises: A Study from Vietnamese stock exchange. Journal of Asian Finance, Economics and Business, 7(1), 47-58. https://doi.org/10.13106/jafeb.2020.vol7.no1.47.

Pedersen. T., \& Thomsen, S. (1999). Economic and systemic explanations of ownership concentration among Europe's largest companies. International Journal of the Economics of Business, 6(3), 367-381. https://doi.org/10.1080/13571519984133.

Putterman, L. (1993). Ownership and the nature of the firm. Journal of Comparative Economics, 17(2), 243-263. https:// doi.org/10.1006/jcec.1993.1025.

Shumway, T. (2001). Forecasting bankruptcy more accurately: A simple hazard model. Journal of Business, 74(1), 101-124. https://doi.org/10.1086/209665.
Vo, V. D., Akbar, Y. H., Nguyen, H. D., \& Nguyen, K. H. (2018). The impact of institutional distance on the choice of multinational enterprise's entry mode: Theory and empirical evidence from Vietnam. Asian Journal of Business and Accounting, 11(1), 71-95. https://doi.org/10.22452/ajba.vol11no1.3.

Vo, X. V. (2014). Foreign ownership, performance and enterprise value - Evidence from listed firms in Vietnamese stock exchange. Journal of Banking Technology, 96, 43-49.

Vu, V. T. T., Phan, N. T., \& Dang, H. N. (2020). Impacts of ownership structure on systemic risk of listed companies in Vietnam. Journal of Asian Finance, Economics and Business, 7(2), 107117. https://doi.org/10.13106/jafeb.2020.vol7.no2.107.

Wei, Z., Xie, F., \& Zhang, S. (2005), Ownership structure and firm value in China's privatized firms: 1991-2001. Journal of Financial and Quantitative Analysis, 40(1), 87-108. https://doi. org/10.1017/S0022109000001757. 